\title{
Family's Role in Preventing Sexual Assaults Against Disable Women in Indonesia
}

\author{
F Rahman', M Rizki², M LHakim ${ }^{3}$ \\ 1,2,3 Department of Govermental Studies Universitas Brawijaya, Malang Indonesia \\ 1athur_rahman@ub.ac.id, ${ }^{2}$ mujirizki@gmail.com, ${ }^{3} \mathrm{em} .1 \mathrm{lukman} 79 @$ @ub.ac.id
}

\begin{abstract}
This paper describes the role of the family concerning their disabled girl as a victim of a sexual assault. Based on the data issued by Indonesian National Commission for Women (Komnas Perempuan) in 2019, the incidence of assaults against women (KtP) continued to increase significantly from 2015-2018. The number of cases of the assaults against women with disabilities (PdD) is alarming in every province.The Province of Yogyakarta occupies the first position with 47 cases; Second, the Province of Jakarta with 13 cases, followed by six cases in ']East Java Province. This data is only the tip of the iceberg because out of the 34 provinces in Indonesia, only 13 provinces have returned the registration form to the National Commission. The findings of this study explain that the occurrence of assaults against women with disabilities (PdD) is due to the weak position of the family in the dimensions of the economy, education, social environment. On the others side, women with disabilities are seen in disgrace. When they become the victims and their moral values are ruined, they are often unable to speak but blamed. The hardship they have experienced shows they need assistance, protection, and comprehensive and sustainable recovery.
\end{abstract}

Keywords: Family, Preventing, Assaults, Women with Disabilities

\section{INTRODUCTION}

Assault involves physical force and power posed to others. Such an assault is intended to control, weaken, or even torture others. Assault could lead to serious implication threatening physical and mental condition of a person, and it is not only punishable by law, but it is also closely related to moral, cultural, political ethics, and personal background. Moore argues that assault could take place due to imagination of a role of a person's identity based on gender connected to the imagination of power one has. This notion helps explain why assault often grows from fear that is visualised by perpetrator as the real feeling of fear [1] Distinguishing sexual feature of male and female stimulates unbalanced relationship pattern [2].This unequal condition leads to coercion posed to another person, or a group of individuals to others [3]. The growing incidence of violence harming women, which is not in balance with the position and relation between victims and perpetrators, just increases the case of assault itself against women. 
FIGURE 1. Incidence of assault against women in four years

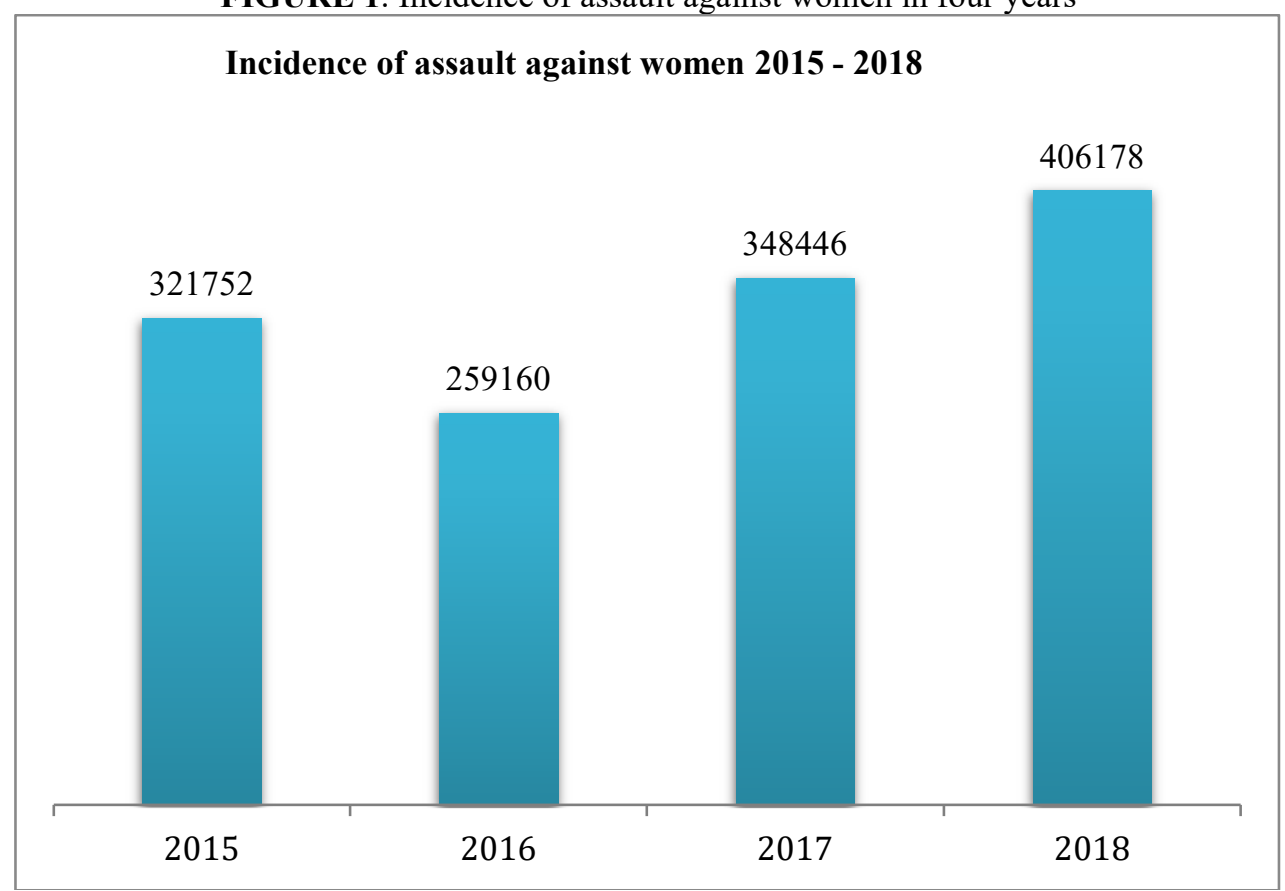

Source: Indonesian National Commission for Women, yearly report 2019

The figure above shows that back in 2015, the incidence of assault accounted for 321,752 , and this figure slightly decreased to 259,160 in 2016 . However, this decrease does not really represent that the case was reduced in number, since there were many victims deciding to not report the violence. It is obvious when the figure rose back even higher in 2017 from 2015, representing 348,446. In 2018, there was an increasing number of women daring to report the case, marked by rising number of cases of assault against women, accounting for 406,178.

It is clearly shown in the figure that cases have widely taken place. Based on the data from Indonesian Commission for Women, assault against women is divided into four: psychological, physical, sexual, and specific types of assault. Psychological form may involve threat, while physical form may involve murder, hit, and torture. Sexual form of assault may involve sexual intercourse, sexual harassment, rape, and molestation.[4] The last category involves human trafficking and assault against migrant workers. Sexual assault in Indonesia is increasing. The data of Indonesian Commission for Women shows that in 2010 there were 2,645 cases, followed by an increase in 2011 to 4,335 cases. In 2012 there were 3,933 cases of sexual assault, and this figure rose back in 2013 to 5,629 cases. In 2014, the incidence accounted for 4,458 of sexual assault. From the document of Indonesian Commission for Women's yearly report on assault against women, the cases reached $23.6 \%(93,960)$ of the total cases of all forms of assault against women reported $(400,939)$.[5] 
Disabled people are limited in agility, and this situation is seen as a chance by healthier people to intimidate those with disabilities through assaults that are mostly perpetrated by men against disabled women. Women were born weak, let alone those with disabilities[6]. Indonesian Commission for Women has some data concerning cases of violence against women. Out of 34 provinces in Indonesia, there were 14 provinces with assault-against-disabled women cases, as shown in the figure below.

FIGURE 2. Cases of assaults against disabled women in 2018

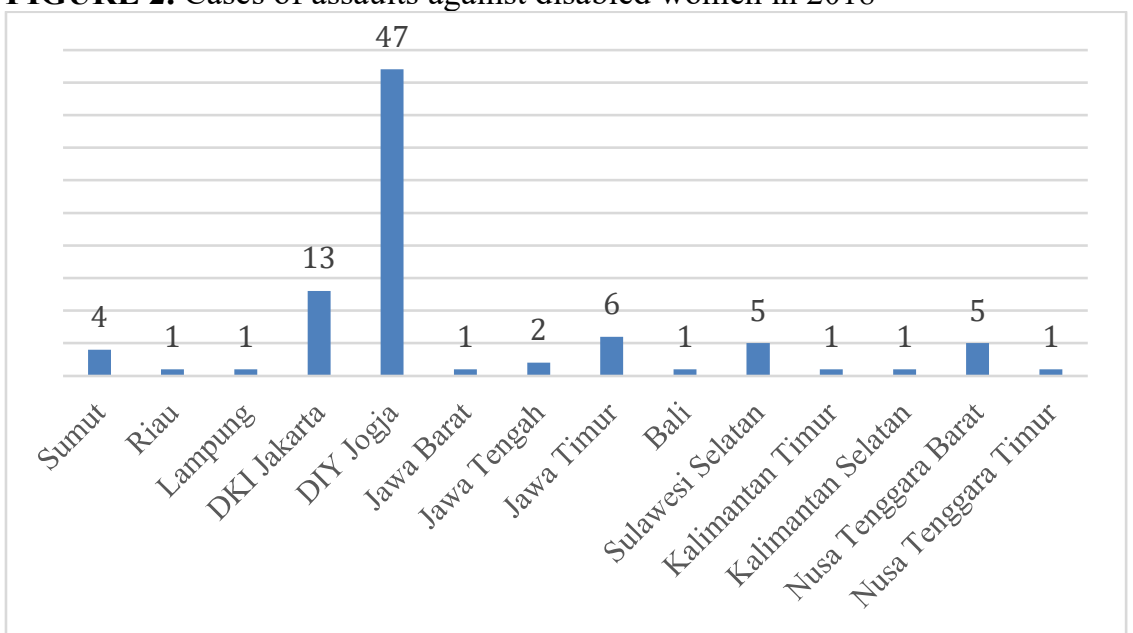

Based on the figure above, Special Region of Yogyakarta had the highest number of case, accounting for 47 cases of assault against women with disabilities, followed by Jakarta with 13 cases on the same ground on disabled women. East Java was the third with 6 cases. Observed more closely, the figure shows unbalanced proportion of cases between Yogyakarta and the other 13 provinces. Out of 34 provinces, there were 13 provinces returning reporting forms to the commission, but it does not mean that other provinces not recorded in the figure are assault-free since several cases that harm disabled women have not been reported.

In ten-year period between 2001-2011, the commission found at least 35 women (including girls) suffered from sexual assaults a day, meaning there were 3 women in Indonesia as sexual assault victims in every two hours (Indonesian Commission for Women, 2018). Within three months in early 2016, from January to March, Forum for Service Providers for Women as Victims of Violence (FPL) received reports and handled 938 cases of violence against women and $45.7 \%$ of the cases were of sexual assaults (Indonesian Commission for Women, 2018). From the details above, this article is aimed to investigate how families take part in preventing sexual assaults against women with disabilities in Indonesia.

\section{RESEARCH METHOD}

According to Sugiyono, a naturalistic qualitative design studies the occurrence of activities and processes naturally, where this method is planned or manipulated [7]. Qualitative methods are generally focused on exploration, disclosure, and inductive logic. The inductive design begins with observation that is specific and built towards general pattern. Analytical dimensions arise from open-ended observation. 
The data used in this research involved primary data, where data was directly obtained in data collection from a key informant. This data involved interviews with the key informant and supplementary informants. The second is secondary data obtained from other parties. This was indirectly obtained from the subject observed. The secondary data was obtained from analytical observation of literature comprising books, scientific journals, research reports, or newspapers.

\section{RESULTS AND DISCUSSION}

Role is based on prescription and the role explains what an individual has to do in a particular situation in order to fulfil his/her expectation or another person's expectation of the role[8]. A role is a set of behaviours expected by others towards a person based on his/her position in a system. Role is influenced by social condition internally or externally, and role is stable [9]. A family's role in educating a disabled child is essential. Protection and role given must be unlimited compared to those given to normal children, especially for young girls with disabilities. This is aimed to protect them from any potential of sexual assaults. Sexual assaults against disabled women are high. This is obvious as reported by Indonesian Commission for Women[10] .

FIGURE 3. Types of Sexual assaults against women with disabilities in 2018

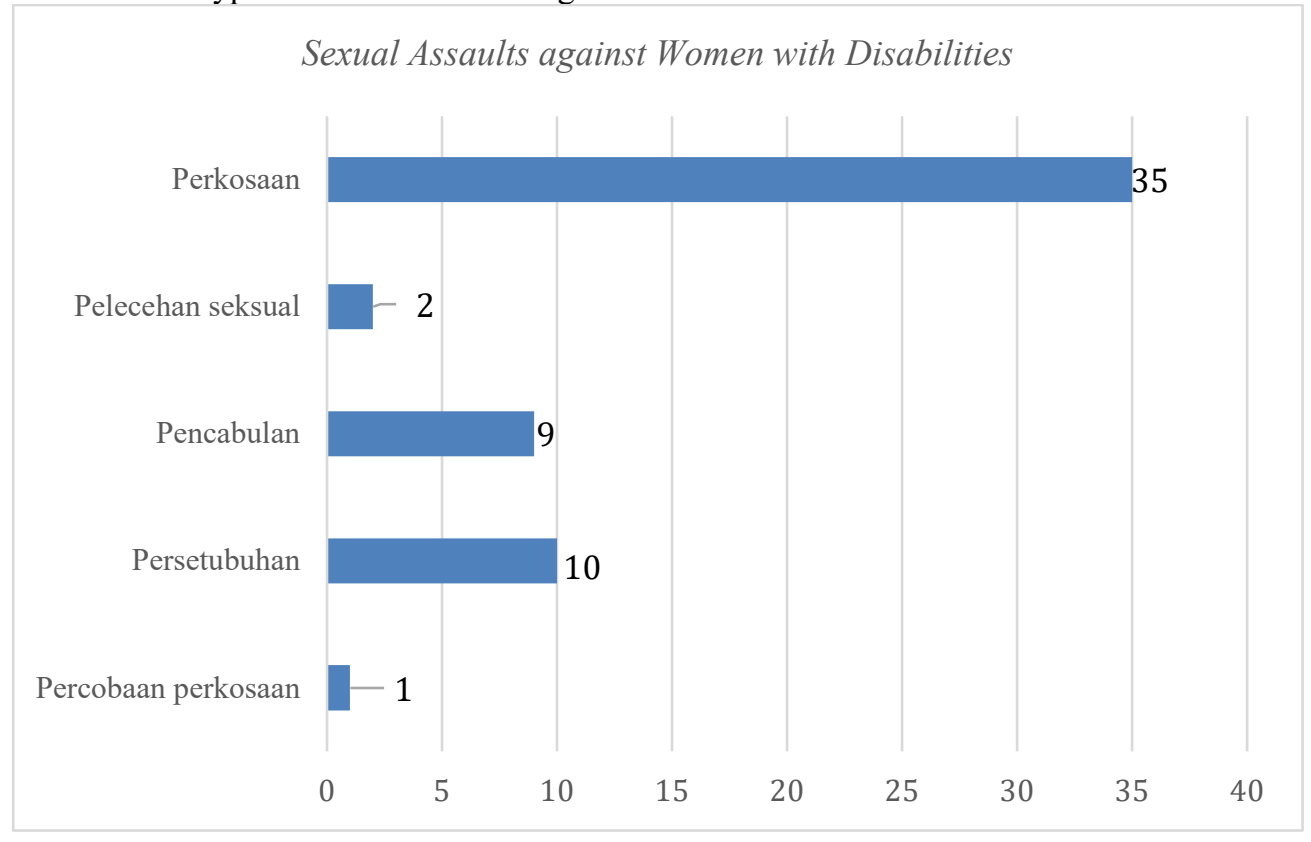

Source: Indonesian National Commission for Women, yearly report 2019

The figure above compares five types of sexual assault against victims. First, rape accounted for 35 cases, followed by sexual intercourse with 10 cases. The third is molestation with 9 cases, followed by the fourth, sexual harassment with two cases. Attempted rape is in the 
fifth with only one case. Sexual assaults against disabled women take place at personal level (in families) and public.

FIGURE 4. Kinds of disabilities in women as assault victims in 2018

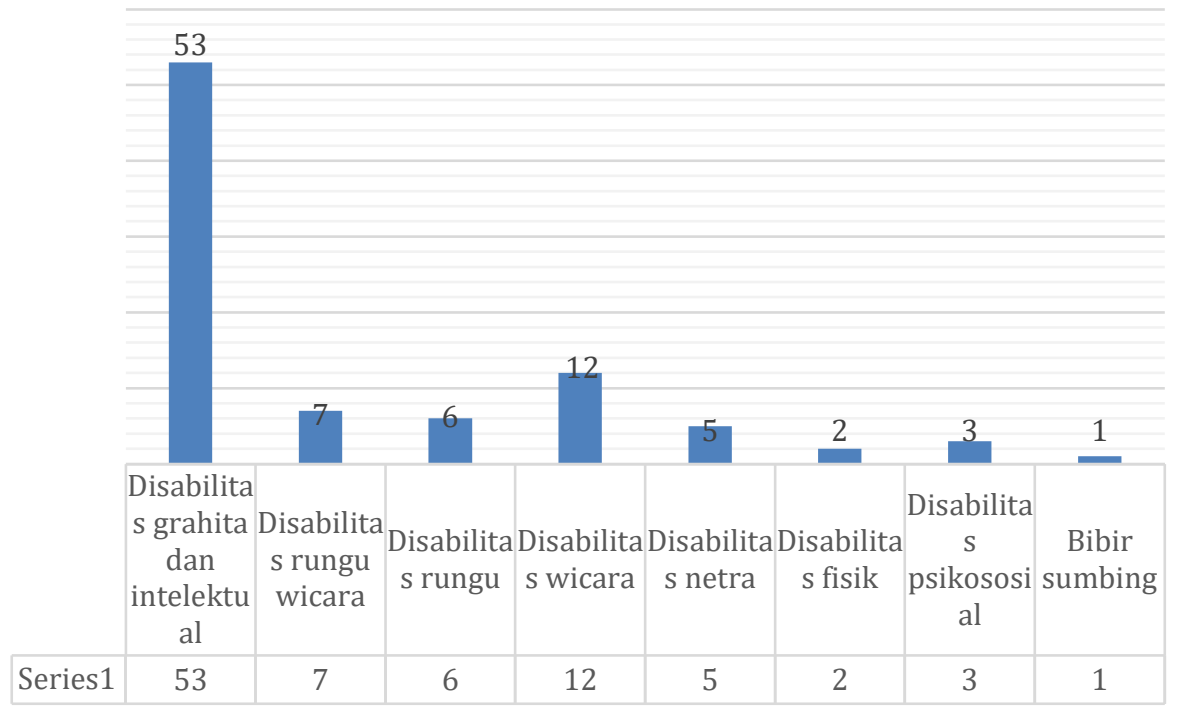

Source: Indonesian National Commission for Women, yearly report 2019

As shown in Figure 4, there are 8 disabilities of victims. The first position is mentally and intellectually disabled, accounting for 53 victims, followed by mute with 12 victims. The deaf-mute and deaf account for 7 victims and 6 victims respectively. The blind, psychologically disabled, physically disabled, and cleft lip represent 5,3,2, and 1 victims respectively. Sexual assaults from which women often suffer take different forms, while to find out in which scope sexual assault is often done against women with disabilities, see the following Figure. 
FIGURE 5. Scopes of assault against women with disabilities 2018

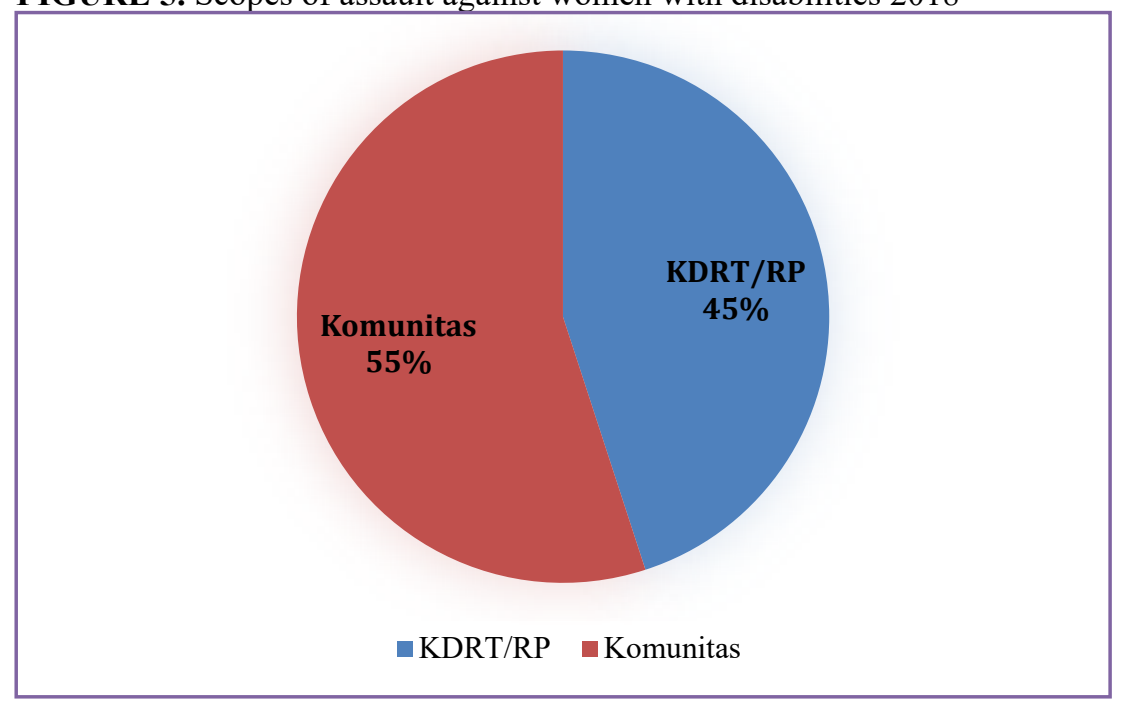

Source: Indonesian Commission for Women, yearly report 2019

The Figure above shows that sexual assault is more common in community, accounting for $55 \%$, while sexual assault in domestic violence/personal relation accounts for $45 \%$. It means that disabled women in community scope are more vulnerable to the assault. Family background is important when disabled women become victims of a sexual assault since family is responsible in this case as a witness, where this status can even bring family further to as defendant. The following is a case example of a sexual assault against a disabled girl:

"A twelve-year-old girl suffered from a sexual assault and she was made pregnant. The law took longer process to settle the case, and it was found that a member of police required money from the victim to fetch the perpetrator. Due to this urgency, the victim's parents were willing to offer their wedding ring instead of the money, but the police refused it. This case ended up with 8 years' imprisonment as decided by court. This tragic case also has implication to the victim's family, where the family was evicted from the house they rented from a landlord. When the family refused to move out, the landlord raised the rent price from IDR 600,000 to a million. It happened since the victim was deemed to have done disgraceful act[11]."

The case above shows that the victim and her family were seen as people with disgrace by their surrounding. When this is the case, the family has to take more part in the condition following the sexual assault. Active participation of the family in post-sexual assault can take the following forms: first, the family should intensively watch and protect the disabled family member, secondly, family is responsible to send the disabled family member to school or at least put him/her busy. When the family is on the breadline, there should be another person trusted to keep an eye on the disabled family member. Third, environment potential with assaults must be avoided especially by those with disabilities in personal scope. Fourth,the victim must not be in contact with family members as perpetrators when sexual assault happens in public scope.

Such a role should be done in a post-sexual assault against a disabled woman, but the role of family in preventing sexual assault is still in question. Surely it will not be wise to prevent 
sexual assaults from happening after many cases have taken place. Factor of family can determine how the role of family in preventing sexual assaults against women should be.

According to Collier, there were five factors such as biology, socio-culture, education, economy, and social learning and motivation, where Education and economy are two detrimental factors of the role of family in preventing sexual assaults against disabled women[12]. Family education is also detrimental in setting a role, but how? Educational background in a family is significantly influential. For example, well-educated parents will have more open thought and such parents often use their logic and are more careful to prevent sexual assaults against disabled women. On the contrary, parents with low education level may not be able to think openly and tend to careless in decision-making.

Economy is another influential factor in preventing sexual assaults against disabled women. A family with good economic provision tends to send their children to school and provide proper medication for their disabled children, while a family with poor economic condition may not care much about their disabled children. In some cases some families even lock their disabled children in stocks with the expectation that they will easily keep an eye on their disabled children.

There are some roles a family of a disabled woman has to play, apart from the factors mentioned earlier. First, the family has to search for information on how much the disabled needs assistance and protection from a sexual assault. Second, other family members have to keep watching every activity the disabled is involved in. Third, a family needs to join community for family with disabled members to help minimise or reduce sexual assaults.

For those with disabilities, independence has to be encouraged, and thus, companion is needed at all time. Family or whoever that can be trusted has to accompany and protect the disabled. It is common to find the disabled not able to refuse an offer from a stranger, easily controlled and intimidated, and having too low scepticism. All these characteristics make them even more vulnerable to sexual assaults[13].

Family's role in educating their disabled family members is essential, and the protection given must be maximum and even more than what is given to normal children, especially for disabled girls. Ministry of Women Empowerment and Child Protection of Indonesia issued guidelines on care for disabled children [14]. In the guidelines, it is stated how parents, family, and society should deal with the disabled in which, first, neglecting a disabled child violates Human Rights. Therefore, parents, family, and society must not hide or neglect the child. Secondly, parents, family, and society must provide special access for the disabled child to religion, education, health, and social life. Third, parents, family, and society need to have a skill to take care of and raise a child with disability through training programs. Fourth, parents and family need to be consistently open to their surrounding in terms of taking care of their disabled child. Fifth, parents and family should be able to stimulate the growth of the disabled child as early as possible both at home and in society[15].

In addition, "more closeness between parents and their disabled child is encouraged to help parents get understanding, awareness, and to encourage them towards positive direction; family has to stimulate the disabled to gain self-assurance to make a decision to avoid any potential of sexual assaults and to be accepted in the society." According to the Head of Indonesian Disabled Women Association (HWDI), Maulani, to avoid sexual assault against disabled women, parents should keep searching for information on how to educate, handle, and communicate with disabled children. Trust from children with disabilities is easily formed, and it is parents' responsibility to keep the trust by protecting them [16]. One of the candidate members of Indonesian Commission for Women, Budi Wahyuni argues that the stigma is deemed to come from the disabled. For example, when sexual assault happens with the disabled as perpetrator, 
the disabled is commonly to blame for being too aggressive, or when the disabled comes as a victim, he/she is deemed asexual. There are some roles the family of disabled women has to play in preventing assault against women apart from the above factors.

\section{CONCLUSIONS}

Sexual assaults harming disabled women have serious impacts on disabled women. Their capacity and authority to testify or give information are often doubted and denied by law enforcers. This state has to have strong fundamentals in the society to encourage the people to respect each other and to lift high the dignity of every person, aimed to protect them from sexual assaults caused by people with stronger physical capability, with power, and with dominance above the vulnerable (women, children, and disabled people). This state has to prevent sexual assault and give priority for victims, bring such a criminal case to court and punish the perpetrators. Last but not least, recuperation has to be facilitated for victims.

\section{REFERENCES}

[1] S. Paterson, “(Re) Constructing women's resistance to woman abuse: Resources, strategy choice and implications of and for public policy in Canada," Crit. Soc. Policy, vol. 29, no. 1, pp. 121-145, 2009.

[2] H. Moore, No Title A Passion of Difference. UK: Polity Press, 1994.

[3] M. Budiardjo, Aneka Pemikiran Tentang Kuasa dan Wibawa. Jakarta: Sinar Harapan, 1984.

[4] M. Rizki, "Laporan Praktik Kerja Nyata: Strategi Perlindungan Perempuan oleh Komisi Nasional Perempuan," Malang, Indonesia, 2018.

[5] "Hasil Catatan Tahunan Komisi Nasional Perlindungan Perempuan Republik Indonesia," Jakarta, 2018.

[6] L. K. N. P. R. Indonesia, "Catatan Tahunan dari Komisi Nasional Perempuan Tahun Kekerasan terhadap Perempuan 2018-2019,” Jakarta, 2018.

[7] Sugiyono, Memahami Penelitian Kualitatif. Bandung: Alfabeta, 2009.

[8] S. Andarmoyo, Keperawatan Keluarga: Konsep Teori, Proses dan Praktik Keperawatan. Yogyakarta: Graha Ilmu, 2012.

[9] B. Kozier, Fundamental Of Nursing. Seventh Edition. Jakarta: ECG, 2008.

[10] L. K. N. P. R. Indonesia, "Catatan Tahunan dari Komisi Nasional Perempuan Tahun Kekerasan terhadap Perempuan 2018-2019.,” Jakarta, 2018.

[11] A. Khusnaeny, Membangun Akses Keadilan Bagi Perempuan Korban Kekerasan: Perkembangan Konsep Sistem Peradilan Pidana Terpadu Penanganan Kasus Kekerasan Terhadap Perempuan (SPPT-PKKTP. Jakarta: Komnas Perempuan, 2017.

[12] R. Collier, Pelecehan Seksual: Hubungan Mayoritas dan Minoritas. Yogyakarta: Tiara Wacana, 1992.

[13] "Pendampingan Penting untuk Cegah Kekerasan Seks pada Anak Difabel," https://www.haibunda.com/parenting/20190308155337-61-33239/pendampinganpenting-untuk-cegah-kekerasan-seks-pada-anak-difabel, 2019.

[14] "Panduan Penanganan Anak Berkebutuhan Khusus Bagi Pendamping (Orang Tua, Keluarga, dan Masyarakat)," https://www.kemenpppa.go.id/lib/uploads/list/b3401panduan-penanganan-abk-bagi-pendamping-_orang-tua-keluarga-danmasyarakat.pdf. Diakses pada 12 November 2019 12:19.

[15] "Seleksi Komnas Perempuan Calon Anggota Komnas Perempuan Soroti Kekerasan 
Seksual Disabilitas," https://tirto.id/calon-anggota-komnas-perempuan-sorotikekerasan-seksual-disabilitas-ejG2 diakses pada 12 November 2019 Pukul 11:36, 2019.

[16] A. DPR RI, Naskah akademik Komnas Perempuan Tahun 2018. Bagian Arsip DPR RI, 2018. 